\title{
DEVELOPMENT OF DENDROMETRICAL INDICES OF SCOTS PINE PINUS SYLVESTRIS L. STAND AFTER THE FOREST DRAINAGE
}

\author{
Aigars Indriksons ${ }^{384}$
}

https://doi.org/10.31410/itema.2018.1115

\begin{abstract}
The work analyses an impact of a drainage system, established in 1939. on overgrown pine tree stand in longer period of time. For the purposes of study 14 sample plots, established by scientists K. Buss and P. Zalitis during the 50's and the beginning of 60's, were remeasured. Sample plots were organized in the Myrtillosa turf. mel., Vacciniosa turf. mel., and Callunosa turf. mel. forest site types. Stands basal area increased in all compared forest site types, maximal being $41.7 \mathrm{~m}^{2} \mathrm{ha}^{-1}$ in Myrtillosa turf. mel. forest site type in 2016. Average diameter and average height of a tree in the stand was also bigger in Myrtillosa turf.mel. forest site type plots. The stand volume in Myrtillosa turf. mel. in 2016 was $384.8 \mathrm{~m}^{3} \mathrm{ha}^{-1}$, in Vacciniosa turf. mel. it comprised $326 \mathrm{~m}^{3} \mathrm{ha}^{-1}$, but in Callunosa turf. mel. it was $259.7 \mathrm{~m}^{3} \mathrm{ha}^{-1}$. The average stand volume in 2016 was $323.5 \mathrm{~m}^{3} \mathrm{ha}^{-1}$. Analysis of statistical parameters showed the substantial impact by the forest site type on diameter and height of the tree. For the inventory of ground cover vegetation, the point-square method was used. 37 plant species from 32 ecological groups were detected at Myrtillosa turf. mel. forest site type plots, 26 species from 23 ecological groups - at Vacciniosa turf. mel., and 23 species from 17 ecological groups - at Callunosa turf. mel. forest site type plots. Ellenberg indicator values, Chekanovsky similarity index and Shannon index for ground cover plants showed the changes of ground cover plant coverage caused by forest drainage. Study results confirm the hypothesis: forest drainage has positive impact on overgrown Scots pine stands dendrometrical parameters and stands growing stock increase. The beneficial effect of hydrotechnical melioration continues even 50 years after reaching the cutting age.
\end{abstract}

Keywords: drained forests, Scots pine, dendrometrical indices, tree increment.

\section{INTRODUCTION}

$\mathrm{T}$ The forest for a long time has been considered as one of most important nature resources for forming and providing of the biosphere. It has a multifunctional importance both in the global and local scale. In Latvia there the forest is significant part of vegetation and, independently from the spatial structure and the dominant tree species, - one of most important elements of the landscape [5].

The forests in Latvia are formed mostly by coniferous tree species; however a considerable part is taken by deciduous trees. The coniferous trees - Scots pine (Pinus sylvestris L.) and Norway spruce (Picea abies (L.) Karsten) are dominating in most part of forest stands. The stands of coniferous trees take $55 \%$ from all stands, birch (Betula sp.) stands $-30 \%$, grey alder (Alnus incana (L.) Moench) - 7\%, and asp (Populus tremula L.) - 4\% [6].

The stands of Scots pine (Pinus sylvestris L.) take approximately $34 \%$ of the total forest area in Latvia [4]. The age structure of pine stands has to been valuated as quite unfavorable, although

\footnotetext{
${ }^{384}$ Department of Silviculture, Latvia University of Life Sciences and Technologies, Latvia
} 
there dominate the stands with an age between 50 and 80 years, and, in the nearest future there is no deficiency of mature stands to be predicted [10].

The positive impact on soil moisture regime in tree stand gives melioration. There are improvement of soil aeration, wood increment, mass increase of needles (leafs) as well the intensifying of tree stand transpiration process taking place [11].

Peatlands are drained to improve the forest increment and productivity in many northern hemisphere countries. The peat soil initially forms of partly decomposed and with water saturated plant residues [2]. Firstly, for the productive growth of trees, there is needed a sufficient aeration of the peat top layer. Decreasing the groundwater level there are the vegetation changes in direction from wetland to forest vegetation by succession [1].

The hydrotechnical drainage is one of most important measures of productive and qualitative management of forest ecosystem. Since its beginnings which are dated with the year 1878, in drained forests are registered tree stand volume changes by performing of measurements of annual rings of trees. The tree stand productivity in coniferous tree species forests is increased 4-10 times after the drainage ditches establishment [12].

The purpose of research is to clarify the impact of hydrotechnical drainage on the dendrometrical indices of overgrown tree stand of Scots pine.

To realize the purpose of research, there are following tasks defined: to analyze the development of Scots pine dendrometrical indices due the time before and after the melioration and changes by reaching of overgrown age of stand; to characterize the ecological condition in forest stand by using of Ellenberg's ecological scales; to give evaluation of further development course of overgrown Scots pine stands in drained forests.

There is following research hypothesis pointed out: the forest hydrotechnical drainage has a positive impact of Scots pine dendrometrical indices and tree stand volume increase also in overgrown age of tree stand.

\section{MATERIALS AND METHODS}

The research object is established in forest stand which is located in Viesīte Forest District of Dienvidlatgale Region managed by Joint Stock Company "Latvian State Forests".

There are 14 sample plots in research object established with the total area of $21000 \mathrm{~m}^{2}$ (size of one sample plot: 30x50 m, area $1500 \mathrm{~m}^{2}$ ) (Figure 1). As the number of sample plots as those areas fit the parameters of historical sample plots established and measured in 1961 by supervision of scientists K.Buss and P.Zalitis. Measurements were performed also in 1984 when instead of previous plots 7 plots were established. The sample plots are located between two drainage ditches, which, according P.Zalitis [9], are established in 1939, and still perform the drainage functions. The distance between the ditches is $432 \mathrm{~m}$. 
Figure 1. Layout of sample plots

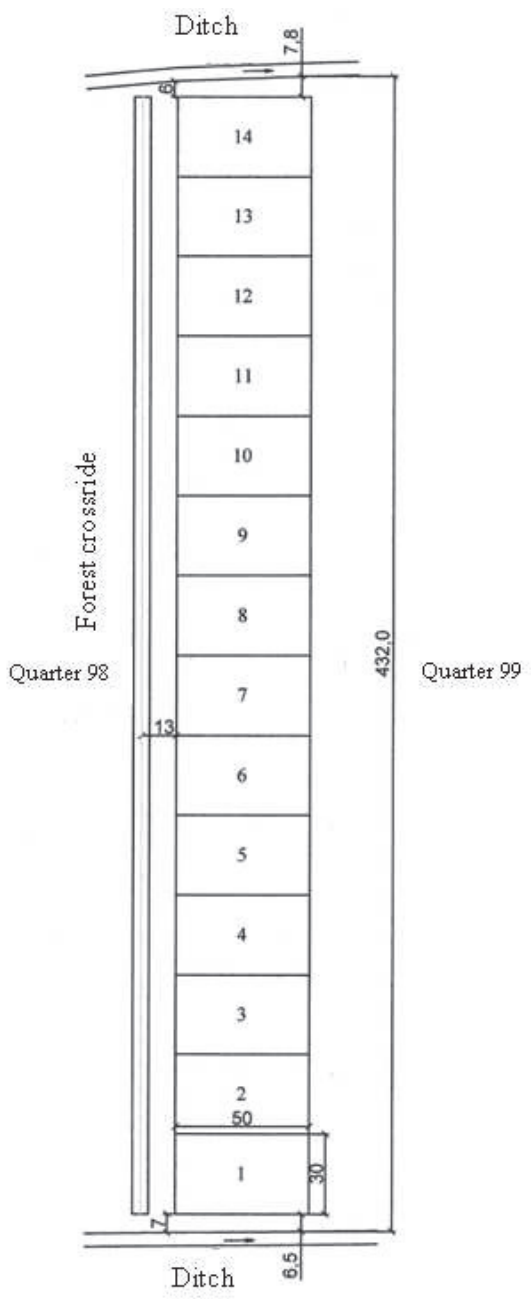

At each plot there numbering of trees performed, the diameter in height of $1.3 \mathrm{~m}$ above the root collar measured. The species of measured trees estimated, the characterization of trees given: the Kraft's class, damages and other properties. For the construction of height curve the height of separate trees was measured by height measurement equipment Vertex.

At every sample plot there are also the ground cover vegetation plants obtained and their abundance estimated. The registration is made by point method. Going across the sample plot with 1 meter long $1 \mathrm{~mm}$ diameter metallic needle there were needle sticks in soil surface made registering all ground cover vegetation plants touching the needle. At each plot there were 200 needle sticks made.

For separate trees there were wood annual rings core drillings made in 2014, to estimate the width of annual rings. The wood annual rings widths were using Lintab annual rings measurement gauge and Leica stereomicroscope measured. The measurements are stored in the T-tools program, which graphically shows the annual rings width at every year of tree growth.

For the estimation of the additional increment, grounding on method elaborated by professor I.Liepa [3], there was the method of the evaluation of environment impact used [8]. The influencing factor in research object is hydrotechnical drainage of forest stand. As methods are 
used data of annual rings width, the diameter and height measurement data of trees from sample plots in different forest site types.

\section{RESULTS AND DISCUSSION}

The number of trees in sample plots is generally reduced, which can be explained with increase of tree stand age and natural decrease of tree stand density by decay of one part of trees.

Since beginning of measurements the total number of trees has reduced for about $51 \%$. Nevertheless, 893 trees per hectare is quite good, indices suggesting about establishment of resistant and stable forest stand.

The basal area of tree stand is one of most important indices of tree stand productivity which has increased in all three forest site types researched.

As the tree stand basal area, as well the total stand volume has been increased (Table 1). In the first five sample plots, corresponding to the growth conditions of Myrtillosa turf. mel. forest site type, in time period between 1961 and 2016, the total stand volume has increased for 206 $\mathrm{m}^{3} \mathrm{ha}^{-1}$. The stand volume of pine and spruce has increases equally, since 1961 increasing for about $107 \mathrm{~m}^{3} \mathrm{ha}^{-1}$. It can be explained with fact that spruce has come more rapidly instead of suppressed or decayed trees, mostly in the place of birch.

The total stand volume in Vacciniosa turf. mel. forest site type since the first measurements in 1961 has increased for about $181 \mathrm{~m}^{3} \mathrm{ha}^{-1}$ or $77 \%$. The pine as the dominant tree species is the most influential in forming of total stand volume. Also the spruce since 1961, when first measurements were performed, the average stand volume has increased for about $65 \mathrm{~m}^{3} \mathrm{ha}^{-1}$.

The stand volume in Callunosa turf. mel. forest site type is practically equal to indices observed in Vacciniosa turf. mel. However the volume of pine stand volume here has increased more rapidly. The birch is presented in small amount - it has been replaced by spruce which stand volume since the beginnings of measurements, here has increased for about $32.8 \mathrm{~m}^{3} \mathrm{ha}^{-1}$.

Table 1. Average stand volume $\left(\mathrm{m}^{3}\right)$ in sample plots with different forest site types

\begin{tabular}{|c|c|c|c|c|}
\hline \multirow{2}{*}{ Year } & \multicolumn{5}{|c|}{ Tree species } \\
\cline { 2 - 5 } & Pine & Spruce & Birch & Pine+Spruce+Birch \\
\hline \multicolumn{5}{|c|}{ Callunosa turf. mel. forest site type } \\
\hline 1961 & 96.7 & 2.6 & 2.9 & 102.1 \\
\hline 1984 & 174.3 & 5.0 & 5.0 & 181.7 \\
\hline 2016 & 222.4 & 35.4 & 1.8 & 259.7 \\
\hline \multicolumn{5}{|c|}{ Vacciniosa turf. mel. forest site type } \\
\hline 1961 & 131.0 & 5.0 & 9.0 & 145.0 \\
\hline 1984 & 219.0 & 28.0 & 4.0 & 252.0 \\
\hline 2016 & 254.0 & 70.0 & 2.0 & 326.0 \\
\hline \multicolumn{5}{|c|}{ Myrtillosa turf. mel. forest site type } \\
\hline 1961 & 148.6 & 19.6 & 10.5 & 178.7 \\
\hline 1984 & 223.3 & 85.0 & 11.3 & 319.7 \\
\hline 2016 & 256.0 & 127.0 & 1.8 & 384.8 \\
\hline
\end{tabular}


As shown in Table 2, the radial increment has increased in all forest site types after establishment of drainage. The increase is most visible in Vacciniosa turf. mel. where it increased for $0.359 \mathrm{~mm}$.

As well the diameter increment, after the beginning of drainage most powerful increased in sample plots with Vacciniosa turf. mel. forest site type being located next to drainage ditches. The value of increase comprises $0.72 \mathrm{~cm}$.

The height increment has gradually increased in plots of all forest site types but especially in Vacciniosa turf. mel. where it increased for $0.08 \mathrm{~m}$. The smallest difference between the increment values is observed in Callunosa turf. mel. forest site type comprising just $0.01 \mathrm{~m}$.

The average stand basal area has more increased in Myrtillosa turf. mel. forest site type, but according to increment indices it has more risen in Vacciniosa turf. mel. - for about $2.23 \mathrm{~cm}^{2}$. As it mostly observed for all types of increment, the smallest changes also for basal area increment are in plots of Callunosa turf. mel. forest site type.

The volume increment in sample plots of all forest site types and thus in forest stand generally has significantly increased. Since establishment of drainage the most rapid volume increment is registered for Myrtillosa turf. mel. forest site type which is represented in first five sample plots. As well the stand volume is higher in these sample plots.

Table 2. The indices of current average periodic increment of separate trees in sample plots

\begin{tabular}{|l|l|l|l|l|l|}
\hline $\begin{array}{l}\text { Time period, } \\
\text { years }\end{array}$ & $\begin{array}{l}\text { Radial } \\
\text { increment, } \\
\mathrm{mm}\end{array}$ & $\begin{array}{l}\text { Diameter } \\
\text { increment, } \\
\mathrm{cm}\end{array}$ & $\begin{array}{l}\text { Basal area } \\
\text { increment, } \\
\mathrm{cm}^{2}\end{array}$ & $\begin{array}{l}\text { Height } \\
\text { increment, } \\
\mathrm{m}\end{array}$ & $\begin{array}{l}\text { Volume } \\
\text { increment, } \\
\mathrm{m}^{3}\end{array}$ \\
\hline \multicolumn{7}{|c|}{ Callunosa turf. mel. forest site type } \\
\hline Till 1939 & 0.88 & 1.76 & 3.49 & 0.23 & 0.0005 \\
\hline $\begin{array}{l}\text { Between } \\
\text { and 2014 }\end{array}$ & 0.903 & 1.81 & 3.54 & 0.24 & 0.0057 \\
\hline \multicolumn{7}{|c|}{ Vacciniosa turf. mel. forest site type } \\
\hline Till 1939 & 0.639 & 1.28 & 1.83 & 0.18 & 0.0003 \\
\hline $\begin{array}{l}\text { Between } \\
\text { and 2014 }\end{array}$ & 0.998 & 2.00 & 4.06 & 0.26 & 0.0058 \\
\hline \multicolumn{7}{|c|}{ Myrtillosa turf. mel. forest site type } \\
\hline Till 1939 & 0.823 & 1.65 & 2.67 & 0.21 & 0.0006 \\
\hline $\begin{array}{l}\text { Between } \\
\text { and 2014 }\end{array}$ & 0.996 & 1.99 & 3.65 & 0.26 & 0.0075 \\
\hline
\end{tabular}

The additional increment of stand volume shows the increase or loss of timber volume which appears by influence of the researched factor [3].

As suggests the results, in all forest site types the width of annual rings most rapidly increased in first decade after the tree stand drainage. However, the additional increment is negative or decreases due the time. In plots of Myrtillosa turf. mel. forest site type, in the first year after drainage (1940) it was $0.24 \mathrm{~m}^{3} \mathrm{ha}^{-1}$, but in year 2014 - just $0.04 \mathrm{~m}^{3} \mathrm{ha}^{-1}$. In plots of Callunosa turf. mel. forest site type there is the additional increment of volume in 2014 is negative comprising $-0.57 \mathrm{~m}^{3} \mathrm{ha}^{-1}$. 
In the plots of Vacciniosa turf. mel. forest site type there are positive changes of the volume additional increment dynamics. At the beginning of drainage it was negative comprising -0.48 $\mathrm{m}^{3} \mathrm{ha}^{-1}$, but due the time has increased and in 2014 reached $0.16 \mathrm{~m}^{3} \mathrm{ha}^{-1}$.

The plants analyzed in plots of Myrtillosa turf. mel. forest site type are medium demanding according to growth conditions. The same can be concluded for Vacciniosa turf. mel. forest site type as suggests the ecological values of Ellenberg. The values of soil $\mathrm{pH}$ and nitrogen availability there are lower as well temperature value. It can be explained with location of plots because the $6^{\text {th }}$ and $7^{\text {th }}$ plots are in about the middle between the ditches, where tree stand is dense and plants are adapted to lower temperature conditions. In plots of Callunosa turf. mel. forest site type the lowest ecological values of Ellenberg are observed for soil $\mathrm{pH}$ reaction and nitrogen. There can be observed that Ellenberg values of light, moisture and continentality are the highest which can be explained with the fact that these plots are located in the middle between the ditches where there is higher soil moisture and the tree stand is less dense thus ensuring more light for ground cover plants.

The similarity coefficient of Chekanovsky shows the similarity of ground cover vegetation between the forest site types. The results suggest that the biggest total similarity of ground cover vegetation is observable between the Vacciniosa turf. mel. and Callunosa turf. mel. forest site types. The smallest vegetation similarity is between Myrtillosa turf. mel. and Callunosa turf. mel. forest site types. Comparing the measurements made in 1961 and 2017, the biggest similarity remains in Vacciniosa turf. mel. but the smallest similarity is in Callunosa turf. mel. forest site type. The conclusions made after the analysis of the coefficients of similarity suggests that during the years the forest ground cover transforms and vegetation succession proceeds.

The biggest abundance in all three forest site types has the Pleurozium plant group, in Callunosa turf. mel. forest site type the number of touching of the given group of plants is 81 . Abundant are also the plants of Hylocomium and Myrtillus groups in all forest site types. From bryophytes there is the Sphagnum fallax group the most abundant, in Myrtillosa turf. mel. having 41 touchings to the needle.

The Shannon index shows the relationship - if the environmental conditions are more stable and the biocenosis older, and then there is bigger species richness.

The Shannon index was calculated for each of plots, as well comprised between the forest site types. The biggest value of Shannon index has been found in $2^{\text {nd }}$ sample plot with forest site type Myrtillosa turf. mel. and, also, if to compare between forest site types, in Myrtillosa turf. mel. the Shannon index is the biggest reaching 4.290. The Shannon index values in Vacciniosa turf. mel. and Callunosa turf. mel. forest site types are quite similar.

The Shannon index values show the highest or maximal value of plant ecosystem diversity. However, it is known that Shannon index is only partly dependent from the number of groups and group's size. This dependence causes difficulties if it is necessary to compare results in different forest ecosystems. Therefore several authors suggest using the relative value of given index, thus the forest ecosystem can be characterized with one index (Pielou index) in limits between 0 and $100 \%$ [7]. Thus the forest ecosystem diversity can be integrated.

The values of Pielou index are the highest in first five sample plots with forest site type Myrtillosa turf. mel. In this forest site type also the abundance of plant ecological groups is the highest. 


\section{CONCLUSIONS}

The number of trees in stand generally continues to reduce, which can be explained by increase of tree stand age and natural selfreducing of stand density. During the last twenty years the total number of trees has reduced for $51 \%$ comprising 893 pieces per hectare. The number of trees has reduced in all forest site types compared. Almost smaller number of trees in 2016 has been found in sample plots with Callunosa turf. mel. forest site type - 675 pieces per hectare.

The average diameter and height of trees for pine is higher in sample plots with Myrtillosa turf. $m e l$. forest site type, reaching $26.7 \mathrm{~cm}$ and $24.1 \mathrm{~m}$ correspondingly.

The tree stand basal area in plots of all forest site types has increased. The most important changes are founded in sample plots with Myrtillosa turf. mel. forest site type where in 2016 the average tree stand basal area was $41.7 \mathrm{~m}^{2} \mathrm{ha}^{-1}$.

The tree stand volume in 2016 in sample plots with Myrtillosa turf. mel. forest site type was $384.8 \mathrm{~m}^{3} \mathrm{ha}^{-1}$, in Vacciniosa turf. mel. forest site type it was $326 \mathrm{~m}^{3} \mathrm{ha}^{-1}$, but in plots with Callunosa turf. mel. forest site type $-259.7 \mathrm{~m}^{3} \mathrm{ha}^{-1}$. The average stand volume in researched forest object in 2016 was $323.5 \mathrm{~m}^{3} \mathrm{ha}^{-1}$.

The similarity of ground cover plants is the highest between the sample plots with Vacciniosa turf. mel. and Callunosa turf. mel. forest site types, but comparing the changes in time, the smallest changes proceeded in sample plots with Myrtillosa turf. mel. forest site type.

The Ellenberg's ecological values, similarity coefficient of Chekanovsky and Shannon's index calculated for ground cover vegetation plants suggest that the hydrotechnical drainage has changed the ground cover vegetation coverage but biological diversity remained.

The increment values estimated for separate trees have increased after the hydrotechnical drainage of tree stand. The almost higher changes are observed for basal area increment dynamics in sample plots with Vacciniosa turf. mel. forest site type where it increased for 2.23 $\mathrm{cm}^{2}$.

The annual additional increment of tree stand volume more rapidly increased in first decade after the forest hydrotechnical drainage decreasing due the time.

\section{REFERENCES}

[1] Laiho R., Vasander H., Penttilä T., Laine J. (2003). Dynamics of plant- mediated organic matter and nutrient cycling following water- level drawdown in boreal peatlands. Global Biogeochem. Cycles 17 (2), 1053, doi:10.1029/2002GB002015.

[2] Laiho R., Penttilä T., Vasander H., Laine J., Alm J. (2006). Post- drainage Dynamics of P uptake by trees and ground vegetation in Scots pine dominated peatlands. SuoseuraFinnish Peatland Society, Helsinki, Suo 57 (1): pp.1-10.

[3] Liepa I. (1996). Pieauguma maciba [Increment science]. Jelgava: LLU. 123 lpp. (in Latvian)

[4] Meza nozare skaitlos un faktos [Forest sector in numbers and facts] (2017). Riga: biedriba „Zalas majas”, p. 5. (in Latvian)

[5] Meza tipologija (2014): macibu lidzeklis LLU Meza fakultates studentiem un nozares specialistiem [Forest typology: study aid for students of LLU Forest faculty and industry 
experts]. I. Liepa, O. Miezite, S. Luguza, V. Sulcs, I. Straupe, A. Indriksons, A. Dreimanis, A. Saveljevs, A. Dreska, Z. Sarmulis, D. Dubrovskis. Jelgava: Latvijas Lauksaimniecības universitate, Meza fakultate. Studentu biedriba „Salkone”. p. 118. Meza izglitibas biblioteka. (in Latvian)

[6] Par Latvijas meziem: Latvijas meza dienests [About Latvian forests: Latvian forest service] [online] [viewed 19.12.2016.]. Available at http://www.lmd.lv/par-latvijasmeziem (in Latvian)

[7] Pielou E. C. (1969). An introduction to mathematical ecology. New York: John Willey.

[8] Vides ietekmes novertesanas metodes algoritma apraksts. Meza resursu ilgtspejigas apsaimniekosanas planosanas lemumu pienemsanas atbalsta sistema [Description of the algorithm of the environmental assessment method. Decision support system of sustainable forest management] [online] [viewed 02.05.2018]. Available at: http://maplas.mf.llu.lv/programs/VFIV_algoritma_apraksts.pdf(in Latvian)

[9] Zalitis P. (1979). Mezaudzes un augsnes hidrologiska rezima parametru izmainas pec nosusinasanas [Changes of parameters of forest stand and soil hydrological regime after drainage]. Jaunakais Mezsaimnieciba 21. Riga: „Zinatne”. pp. 17. (in Latvian)

[10] Zalitis P. (2005). Skuju koku mezi [Coniferous forests]. No: Celvedis Latvijas privato mezu ipasniekiem. Riga: LVMI „Silava”: Et cetera. p. 169. (in Latvian)

[11] Zalitis P. (2006). Mezkopibas prieksnosacijumi [Preconditions of silviculture]. Riga: LVMI „Silava”: Et cetera. p. 219. (in Latvian)

[12] Zalitis P., Jansons J., Indriksons A. (2013). Mezaudzu parametri hidrotehniski melioretajos mezos pedejos piecdesmit gados [Variations in stand parameters in hydrotechnically drained woodlands over the last fifty years]. Mezzinatne 27(60), pp. 36-66. (in Latvian) 